NBER WORKING PAPER SERIES

\title{
ARE MENTAL HEALTH INSURANCE MANDATES EFFECTIVE?: EVIDENCE FROM SUICIDES
}

\author{
Jonathan Klick \\ Sara Markowitz \\ Working Paper 9994 \\ http://www.nber.org/papers/w9994
}

\author{
NATIONAL BUREAU OF ECONOMIC RESEARCH \\ 1050 Massachusetts Avenue \\ Cambridge, MA 02138 \\ September 2003
}

The authors would like to thank Jennifer Tennant, Dan Grossman and Richard Flom for excellent research assistance. In addition, we would like to express our appreciation for helpful comments and suggestions provided by Peter Loeb, Ted Joyce, Will Dow and participants at the NBER Summer Institute in Health Economics. The views expressed herein are those of the authors and are not necessarily those of the National Bureau of Economic Research.

(C)2003 by Jonathan Klick and Sara Markowitz. All rights reserved. Short sections of text, not to exceed two paragraphs, may be quoted without explicit permission provided that full credit, including (C) notice, is given to the source. 
Are Mental Health Insurance Mandates Effective?: Evidence from Suicides

Jonathan Klick and Sara Markowitz

NBER Working Paper No. 9994

September 2003

JEL No. I0, K0

\section{$\underline{\text { ABSTRACT }}$}

Many states have passed laws mandating insurance companies to provide or offer some form of mental health benefits. These laws presumably lower the price of obtaining mental health services for many adults, and as a result, might improve health outcomes. This paper analyzes the effectiveness of mental health insurance mandates by examining the influence of mandates on adult suicides, which are strongly correlated with mental illness. Data on completed suicides in each state for the period 1981-2000 are analyzed. Ordinary least squares and two-stage least squares results show that mental health mandates are not effective in reducing suicide rates.

Jonathan Klick

The American Enterprise Institute

1150 Seventeenth Street, NW

Washington, DC 20036

jklick@aei.org

Sara Markowitz

NBER

365 Fifth Avenue, $5^{\text {th }}$ Floor

New York, NY 10016

and Rutgers University, Newark

smarkow@newark.rutgers.edu 


\section{INTRODUCTION}

Mental illnesses are debilitating diseases affecting millions of people each year. These conditions constituted five of the top ten leading causes of disability worldwide in 1990, measured in years lived with a disability. Unipolar depression is the largest cause of disability (Murray and Lopez 1996). Despite the severity of the burden of mental illness, many cases of mental disorders remain untreated. Estimates show that about 28 percent of the U.S. adult population in any year has a diagnosable mental or addictive disorder, yet only 8 percent seeks treatment (USDHHS 1999).

In response to the increasing scope of the problems associated with mental illness, coupled with improvements in the diagnosis and treatment of mental disorders, a number of states and the federal government have taken steps to improve access to mental illness services in the form of mandated mental health benefits, including mental health parity laws. These laws have the potential to lower the effective price of mental health services, increasing utilization. However, it is possible these laws might raise the cost of providing insurance thereby reducing access.

Evaluating the effectiveness of mental health insurance mandates requires analysts to answer three major questions: 1) do mandates successfully lower the price of obtaining mental health services; 2) do mandates increase access to mental health services; and 3) do mandates contribute to improvements in mental health outcomes? Conclusive answers to these questions are elusive, primarily because work in this area suffers from significant data limitations. While existing research provides some insights into the first two questions, no research to date attempts to answer the third question.

This paper examines the question of whether or not mandates directly contribute to 
improvements in mental health. The answer to this question is crucial to policymakers at the state and federal levels as they consider implementing and expanding mental health insurance mandates. The results of this study provide evidence of the impact of mental health and substance abuse treatment mandates, including parity laws, on adult suicides, a measurable outcome of poor mental health. In considering the efficacy of mental health mandates in reducing suicides, instrumental variables are used to control for potential simultaneity between suicide rates and mandate adoption. The results indicate that mental health mandates are exogenous, and they are also ineffective in reducing suicide rates.

In the sections that follow, background information is provided regarding the impetus for the mental health insurance mandate movement, as well as a discussion of prior analyses of the effects of mandates. We then discuss research design, data, and empirical results, concluding with directions for future research.

\section{BACKGROUND}

Although a few states enacted mental health insurance mandates in the 1970s and 1980s, a nationwide push for mandates, especially so-called mental health parity mandates, began in earnest in the early 1990s. Mental health parity laws require insurers to provide parity in coverage between mental health and physical health coverage. These laws typically prohibit insurance companies from offering plans that place greater financial burden on access to diagnostic or treatment services for mental health conditions than for physical health conditions. Such laws are designed to lower the price of mental health services faced by insured individuals, improve access to treatment, and ultimately to improve mental health outcomes. Other types of laws include mandated mental health benefits and mandated mental health benefit offerings. 
By 2002, forty-six states mandated some form of mental health benefit, but the specifics of those laws vary widely. Some require full parity in which insurers must provide mental health benefits at exactly the same terms applying to physical health benefits. Other mandates simply require that a minimum level of mental health coverage be provided or offered, with varying equivalence requirements and pricing restrictions. Further, some states define mental illness broadly, applying their mandates to virtually any illness listed in the American Psychiatric Association's Diagnostic and Statistical Manual, while other states limit the conditions covered by the laws to a few "biologically based" illnesses, such as schizophrenia, bipolar disorder, and major depressive disorders. Some states have exemptions for small businesses and large cost increases. One particularly visible distinction is whether or not the laws cover treatment for substance abuse and addiction. Roughly half of the states with mandated mental health benefits explicitly include addiction treatment, while about a quarter explicitly exclude it from the mandate.

In addition to the success in passing mandates at the state level, mental health advocates argue that federal mental health parity legislation is necessary. Many employers are unaffected by state insurance regulations due to the federal pre-emption granted by the Employee Retirement Security Act (ERISA) of 1974. ERISA effectively pre-empts state regulation of selffunded health insurance plans. That is, ERISA disallows individual states from imposing health insurance mandates of any kind on any firm that self-insures. Self-insured plans are typical of large employers, and as a result, employees of large companies are not likely to benefit from state mandates regarding mental health benefits. These self-insured plans represent about onethird of workers with employment-based insurance (EBRI 2000).

The federal Mental Health Parity Act of 1996, which became effective in 1998 and was 
eventually extended through the end of 2002, was passed to fill the regulatory gap created by the ERISA exemption. The federal parity mandate prohibited group health insurers providing mental health benefits from imposing annual and lifetime expenditure limits for mental health treatments that are stricter than those applying to physical health treatments. However, this law did not impose any conditions on deductibles, copayments, or days covered, nor did it include provisions for substance abuse treatment. More important, the law did not require employers to offer mental health coverage, leaving employers the option of dropping mental health benefits altogether. The law also contained two major exemptions. The first exempted small employers with 50 of fewer employees. In 2000, small firms employed approximately 28 percent of the labor force. The second exemption arose if the law resulted in a cost increase of at least one percent of medical costs.

\section{EXISTING EVIDENCE ON EFFECT OF MANDATES}

The extent to which mental health mandates improve the welfare of individuals with mental illnesses is ambiguous. Although supporters of the mandates deem them necessary to solve apparent "market failures" in the provision of mental health insurance, there is conflicting evidence on the issue of whether coverage mandates improve access to mental health services.

Shortly after a number of states enacted minimum mental health benefit laws, researchers began to evaluate the effectiveness of such laws on access to care. McGuire and Montgomery (1982) examined the impact of the laws on hours of practice by fee-for-service psychiatrists and psychologists in 1978. Their findings suggest that mental health mandates increase service use, but these estimates are statistically insignificant. Using a panel of states during the 1970s, Frank (1985) reaches a similar conclusion in his study on visits to psychiatrists. He finds that mental 
health mandates increase the demand for services by 12-22 percent, but again, these estimates are imprecise. Horgan (1986) finds that mandated private insurance coverage increases the probability of using ambulatory mental health services in the specialty sector, while simply mandating the availability of benefits has no effect on use. She also finds that neither mandated private insurance coverage nor mandated availability of benefits has any effect on the number of visits among users who have out-of-pocket expenses for mental health treatment.

Opponents of insurance mandates in general often claim that mandates increase the cost of insurance, inducing employees or firms to drop health insurance altogether (Economic Report of the President 1991). Gruber (1994) presents evidence that this displacement effect of mandates is virtually non-existent. Using data from the May CPS supplements data 1979, 1983 and 1988, Gruber finds that state mandates to cover certain health services, including alcohol, drug abuse and mental illness, have no impact on the probability that an employee of a small firm is covered by health insurance. There is some evidence, however, that alcohol treatment mandates lower the probability that a small firm will offer insurance. Gruber explains that mandates in general might be ineffective since firms generally offer benefits that exceed the mandated minimums.

Kaestner and Simon (2002) also examine the displacement effect of state health mandates on the private provision of health insurance benefits by small employers. Focusing on the total number of health mandates in a state, they find that such mandates have no impact on the prevalence of health insurance coverage for full-time and part-time employees in small firms. A similar conclusion is reached when examining the joint effect of four high-cost mandates; drug treatment, alcohol treatment, mental health care and mental health parity.

Parity mandates, however, might generate different effects than minimum benefit 
mandates since they tie mental health benefits to physical health benefits. That is, parity mandates do not only affect the cost of providing insurance for mental health treatments, they also indirectly affect the cost of providing traditional health insurance. If a firm wishes to increase its physical health benefits, parity mandates require a concomitant increase in mental health benefits as well. This joint determination generates an ambiguity in the effect of mandates on access to mental health treatments.

Some researchers suggest that the costs of increased mental health benefits are at least partially offset by the benefits employers enjoy due to improved mental health among their workers. The financial offset argument claims that providing mental illness coverage reduces other costs borne by employers. England (1999) makes this case with respect to depression, claiming that employers lost $\$ 24$ billion due to lost work time and productivity in 1993 as a result of untreated depression among their employees. Olfson et al. (1999) note that these indirect cost savings might be particularly important with respect to treatments for alcoholism, citing evidence that early treatment of the disorder can eliminate many costs due to alcoholinduced long term physical health disorders, such as cirrhosis, cardiomyopathy, and chronic hepatic encephalopathy.

In resolving this theoretical ambiguity, it is difficult to ascertain the causal effects of mandates on access to mental health services because adoption of the mandates appears to be endogenous to underlying state characteristics, which also affect access to care. For example, Sturm and Pacula (1999) document that states with below average use rates of mental health services are more likely to pass mandates, and, even after adoption, those states continue to lag behind national averages. Recognizing this simultaneity, Pacula and Sturm (2000) use a twostage procedure on a sample of individuals over a one-year period to estimate the impact of 
parity laws on mental health service utilization. They find no difference in the level of mental health service utilization among people living in states with parity laws compared to those living in states without parity laws. They speculate that this finding is generated by an insurance displacement effect for high-risk individuals. A major problem with such individual level data is that details of the respondent's employment situation and/or health insurance coverage are often unknown. This information is vital given that many insurance plans are exempt from state mandates and the lack of such information can bias results.

Sturm (2000) uses data from the Health Tracking Initiative, which is designed to track changes in health care over time, to analyze the effect of parity laws on insurance coverage for individuals with mental health disorders. Using a difference-in-difference estimation strategy, this study finds that mentally ill individuals living in states with parity laws are more likely to lose insurance coverage, although the benefits for those retaining coverage is generous and access to care is easier. These estimates, however, are small in magnitude and statistically insignificant.

The presumption against the efficacy of mandates is strengthened by results suggesting that access to mental health services has increased even in the absence of mandates. Zuvekas et al. (2002) find that while treatment prevalence increased by 50 percent in one employer group during the three year period after mental health parity mandates were enacted, a similar increase occurred in employer groups that were not subject to the mandate. Research on the effects of the federal mental health parity law has shown very few changes in plans as a result. The Substance Abuse and Mental Health Services Administration found that almost half of all eligible employers were already in compliance with the act prior to its effective date. Sixty-eight percent of the plans reported no change in benefits as a result of the law, and almost none chose to drop 
mental health coverage (SAMHSA 1999).

Dissimilarities in treatments between mental illness and physical illness also induce some limitations on the effect of parity laws in improving access to mental health services. Frank et al. (2001) point out that many important aspects of mental health treatments have no counterpart in standard medical care, leaving them unaffected by parity laws. For example, many health insurance plans do not cover residential treatment programs or day-hospital care. In some cases, these components of treatment might be necessary for effective mental health treatment. A General Accounting Office (2000) survey indicates that many employers compensate for the changes in limits by imposing restrictions on aspects of mental health treatment not covered in the federal parity mandate.

It is an open question then as to whether mental health insurance mandates improve the welfare of those facing mental illnesses. Direct evidence about the effect of mandates on the benefits provided to employees does not resolve the questions about the efficacy of mental health mandated benefits and parity laws.

\section{ANAYTICAL FRAMEWORK}

The model of mental health used is derived from Grossman (1972) and involves a mental health production function and input demand functions:

1) $\mathrm{M}=\mathrm{m}(\mathrm{Tm}, \mathrm{A}, \mathrm{D}, \mu)$,

Equation 1 posits that good mental health $(\mathrm{M})$ is a function of mental health treatment $(\mathrm{Tm})$, alcohol and/or drug consumption (A), demographic and socio-economic factors (D), and unobserved individual factors, which might include a genetic endowment of health $(\mu)$. It is assumed that alcohol and drug consumption have a negative impact on good mental health 
whereas treatment has a positive impact. ${ }^{1}$

Alcohol and drug consumption, as well as treatment services face the following demand functions:

2) $\mathrm{A}=\mathrm{a}(\mathrm{M}, \mathrm{Ta}, \mathrm{Pa}, \mathrm{Y}, \mathrm{D}, \mu)$.

3) $\mathrm{Tm}=\mathrm{t}(\mathrm{A}, \mathrm{Ptm}, \mathrm{Y}, \mathrm{D}, \mu)$,

4) $\mathrm{Ta}=\mathrm{t}(\mathrm{A}, \mathrm{Pta}, \mathrm{Y}, \mathrm{D}, \mu)$,

Equation 2 represents the demand function for alcohol or drugs where consumption is determined by mental illness, price $(\mathrm{Pa})$, income $(\mathrm{Y})$, demographic factors and unobserved individual factors. Consumption can be lowered through substance abuse treatment services (Ta). Equations 3 and 4 are demand functions for mental health and substance abuse treatment services, respectively. Here, treatment levels are determined by drug and alcohol consumption, prices (Ptm, Pta), income, demographic factors and unobserved individual factors. The prices of treatment faced by individuals may be affected by insurance coverage.

A reduced form model of mental health serves as the basis for empirical estimation:

5) $\mathrm{M}=\mathrm{m}(\mathrm{Ptm}, \mathrm{Pta}, \mathrm{Pa}, \mathrm{Y}, \mathrm{D}, \mu)$.

Equation 5 is derived by substituting equations 2, 3 and 4 into equation 1 . The estimation of equation 5 will show the direct effectiveness of reductions in mental health and substance abuse treatment prices in improving mental health status.

Mandates are intended to lower the price of obtaining mental health and substance abuse treatment services, therefore, indicators for the presence of these laws in each state will be used to represent price. Mandate adoption will serve as a proxy for changes in the price of treatment through changes in insurance coverage.

\footnotetext{
${ }^{1}$ There exists a complex relationship between substance use and mental illness, with many researchers believing that substance use contributes to deteriorating mental health (Egelko et al. 2002; Havassy and Arns 1998).
} 


\section{EMPIRICAL MODEL AND DATA}

In order to estimate equation 5, a valid measure of mental health is needed. Previous studies examine the impact of mental health parity laws on mental health service utilization (Pacula and Sturm 2000; Zuvekas et al. 2002) and insurance coverage (Sturm 2000), but none has looked directly at mental health outcomes. We take this approach and use a measurable outcome of mental health services, suicide. Suicide is a useful outcome for a number of reasons.

First, suicide is strongly correlated with mental illness. Researchers believe that almost all individuals who commit suicide have a diagnosable mental disorder (Maris et al. 1992). It has been estimated that two-thirds of people who commit suicide have a depressive illness; 5 percent suffer from schizophrenia; and 10 percent meet the criteria for other mental illnesses including borderline personality disorder. However, only half of people who die by suicide receive any mental health treatment in their lifetimes (Maltsberger 1992; Clark and HortonDeutsch 1992).

Second, parity legislation is often intended primarily to benefit the most severely ill patients (Sturm 2000). For example, the federal law only affected annual and lifetime dollar limits, which are likely to be reached only by the severely ill. The risk of suicide is highly correlated with the intensity of treatment. Simon and Von Korff (1998) find that among insured patients receiving treatment for depression, the highest risk of suicide was among those receiving inpatient treatment and medication. The lowest risk was found among individuals receiving outpatient treatment without medication.

Lastly, suicide is related to both substance use and mental illness. Since many of the mental health mandates include both substance abuse and mental health treatment, a desirable 
health outcome is related to both substance use and mental illness. Suicide meets this criterion. Alcohol abuse disorders are found in approximately 25 percent of completed suicides cases, and 20-25 percent of suicide victims are intoxicated at the time of death (Murphy 1992; Goldsmith et al. 2002).

For the conclusions of this study to be useful, not only must the demand for treatment be affected by parity laws, but treatment itself must affect the suicide rate. Previous research in economics has shown that the treatment of mental illness is responsive to price, and while the elasticity of demand is fairly inelastic, it has been estimated to be more price responsive than general health (see Frank and McGuire 2000 for a review of the literature). The answer to the question of whether treatment is successful in lowering suicides is much more elusive. It is nearly impossible to estimate how many suicides are avoided through the provision of mental health services, although advances in psychopharmacology have often been credited with improving mental health outcomes and suicide rates. For example, a recent study of suicides in Australia found a strong, negative correlation between suicides and sales of antidepressants (Hall et al. 2003). The reduction in suicide rates might be a result of the use of the drugs, or it might reflect increased diagnosis and treatment of depression by psychiatrists or general practitioners, since the prescription of antidepressants is typically accompanied by other interventions such as counseling which may also reduce suicides.

Each state's suicide rate for adults ages 25-64 is used as the measure of the mental health status of each state's population. Data on completed suicides come from the National Center for Health Statistics's Compressed Mortality File, which contains information on all completed suicides over time. These data are collected from death certificates filed in each state and include the state of residence, age, race, and gender of each individual. 
Focusing on the suicide rates as a measure of mental health, the empirical equation takes the following form:

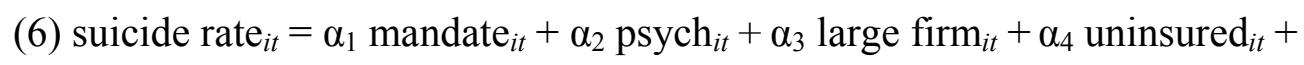

$$
\alpha_{5} \text { medicaid }_{i t}+\Theta \mathrm{X}+\lambda_{i}+\tau_{t}+\varepsilon_{i t}
$$

where the dependent variable is the adult suicide rate in state $i$ during year $t$. The primary covariate of interest is the mental health mandate variable, which is an indicator taking the value of one if state $i$ has a mandate during year $t$ and zero otherwise. As described below, three different mandate categories are examined. Next, the per-capita number of psychiatrists is included, as are the fraction of state $i$ 's workforce employed in large firms during year $t$ (large firms), the fraction of state $i$ 's population without insurance during year $t$ (uninsured), and the fraction of state $i$ 's population on Medicaid during year $t$ (medicaid). The vector $\mathrm{X}$ represents other state-specific characteristics that might be related to suicide rates. Time invariant state effects $(\lambda)$ are included, as well as year effects $(\tau)$ that are common to all states during time $t$.

There exist tremendous differences in the scope and provisions of mental health insurance mandates across states and time. Using categories created by the National Conference of State Legislatures and consulting the state statues, the state laws are grouped into three mental health mandate categories (NCSL 2003). The first mental health mandate is a very broad category termed "any mental health mandate" and includes all states that have some type of mandate in effect. The laws could apply to all insurance plans or only to plans that offer mental health benefits. It includes those laws requiring that mental health benefits be provided on parity with physical health benefits and those laws that simply require a minimum level of mental health coverage be provided or merely offered. The second category represents laws mandating that all health insurance plans provide mental health benefits. Termed "required mental health 
benefit," this category is different than the first in that firms must provide benefits. This measure includes the states with parity laws and the many states and time periods for which the mandated benefits are not necessarily on parity with physical health. The last indicator is termed "parity law" and represents those state laws that require the provision of mental health benefits on parity with physical health. Note that according to this definition, parity might apply to cost sharing, days, and/or lifetime and annual limits. ${ }^{2,3}$

We caution that it is difficult to categorize the various mental health insurance mandates into specific groupings in any consistent way, given the varying language used in the statutes. Even in cases where essentially the same wording is used, the interpretation of each statute is conditional on existing judicial precedent and the policies of regulatory agencies within the state. If we abstract away these institutional differences and focus on the plain language meaning of the statutes, it is still generally not possible to categorize the mandates in a principled way. For example, although there is a temptation to treat mandatory benefit statutes differently from mandatory offering statutes, in many cases the difference is merely nominal. That is, there is very little practical difference between a mandatory offer and a mandatory benefit as long as the pricing restrictions and benefit levels are equivalent, since under each regime a consumer will be covered for the stipulated services if he chooses to elect them. With that in mind, in many ways, the general category of mandates is the least arbitrary, though it is unclear whether parsing the mandates would help us achieve greater precision in the estimates. For this reason, we rely on multiple groupings to examine the robustness of our estimates.

\footnotetext{
${ }^{2}$ Other studies and sources of the laws use different definitions for "parity" states. For example, Sturm and Pacula (1999) include in the group of parity states those which require parity, but do not necessarily mandate benefits. ${ }^{3}$ A fourth category of laws was tested representing substance abuse treatment mandates. Our characterization of these laws is incomplete, however, since a number of states have substance abuse treatment laws which are separate from their mental health benefits laws. Analyzing the impact of these laws is beyond the scope of this paper, but is a subject for future research.
} 
The percent uninsured, the percent on Medicaid, and the percent employed by large firms are included in all models to help mitigate a potential bias resulting from heterogeneity in coverage. The uninsured are not covered by the mental health mandates imposed on insurance companies, nor are other sub-populations such as people on Medicare and Medicaid. ${ }^{4}$ Further, the ERISA pre-emption exempts all self-insured employers and their employees from the provisions of the state laws.

Unfortunately, the suicide data cannot identify an individual's coverage status, although we do include only those suicides by individuals under the age of 65 to eliminate any effect of the Medicare population on the results. The fact that the suicide data include both covered and uncovered individuals effectively biases the results toward zero since, in theory, the estimated effect of a law is a weighted average of a zero effect (for those not covered) and the effect of those covered by the laws. To capture some of this coverage heterogeneity, the percent of each state's population that is uninsured and the percent covered by Medicaid are included in all models. To account for the effect of ERISA pre-emption, the percent of a state's workforce that is employed by large firms (over 500 employers) that are likely to fall under ERISA is included. Consistent data (cross sectional by state or time series within given states) on ERISA coverage are not available, however, large employers are much more likely to self-insure than smaller companies (EBRI 2000), therefore, the percent of employees in large firms may serve as a valid measure of scope of the ERISA exemption.

Next, the number of psychiatrists per capita is included in all models. This variable is important to include because it is likely to be correlated both with the suicide rate and the mandated benefits. The number of psychiatrists might affect suicides by influencing the full

\footnotetext{
${ }^{4}$ Medicare provides both inpatient and outpatient mental health benefits. Medicaid also provides mental health services, but to varying degrees based on the state.
} 
price of receiving mental health treatment through availability of services, and it might influence the passage of mental health mandates through a strong lobbying effort. We caution that this variable could be endogenous if the observed level reflects the overall mental health status of the state population, with more psychiatrists demanded in states with higher rates of mental illness. However, its inclusion helps to reduce the correlation of the mandates with the error term in the suicide equation, particularly in the OLS equations. The endogeneity of mandates is discussed further below.

Lastly, a number of other state-level variables are used as covariates to represent the demographic and socio-economic status of each state's population. These variables include the female labor force participation rate, the unemployment rate, real income per capita, the percentage of the population living in rural areas, the percentage of the population 25 years and over that has obtained a bachelor's degree, and the real (1982-1984 dollars) state excise tax on beer. Previous research has found many of these state characteristics to be important determinants of suicide rates (see for example Maris et al. 1992; Cutler et al. 2001; and Markowitz et al. 2003). Descriptive statistics and sources for all variables are presented in Table 1.

\section{ESTIMATION ISSUES}

A simple population weighted OLS estimation of suicide rates on parity laws and state characteristics provides a baseline estimate of the effectiveness of the laws. This specification might prove to be biased due to simultaneity between parity adoption and suicide rates. Sturm and Pacula (1999) find that parity legislation is more likely to be passed in states where mental heath service use is low, indicating a potential reverse causality from mental health outcomes to legislation. It is possible that states with high suicide rates are more likely to pass parity 
legislation in response to the poor mental health status of the population. Note that this proposition depends on the factors influencing legislators' decisions to enact such mandates. Suicides are fairly rare events and are typically not publicized for fear of encouraging copycat deaths. As a result, legislators might not be influenced by the suicide rate per se in passing mental health legislation. Nevertheless, two-stage least squares (TSLS) will be used to test for and correct for the potential endogeneity in the parity laws. The instruments used include variables relating to politics and policy.

The first instrument is an indicator measuring whether or not the state has enacted an insurance mandate with respect to diabetes. That is, many states, during the same time period used here, considered laws requiring insurers to cover medical treatments for diabetes, such as insulin, diabetes pills, and dialysis treatments. Passage of a diabetes mandate is likely to be an indicator of a state's willingness to mandate coverage in general and, accordingly, should be correlated with the passage of parity laws. There is no reason to suspect that diabetes coverage and suicide rates are directly related.

Next, the percent of each state's congressional representatives that are Republican and the percent of Republicans in each state's lower house are used in some specifications as additional instruments to capture the political preferences of a state's voters. These preferences are likely to be correlated with mandate adoption, and there is no reason a priori as to why they should be directly related to suicide rates. In the empirical estimation, these variables have little predictive power in many specifications. Angrist and Krueger (2001) discuss the bias in the twostage least squares coefficient as a result of weak instruments. Reducing the number of instruments can reduce this bias, therefore, the results are shown for models that include and exclude these two Republican Party variables. 
All models include a series of dichotomous indicators for each state in order to account for any unobserved state-level factors that may influence both the mental health mandates and suicide rates. One common problem in policy research with including these dummy variables is that they often are highly correlated with the variables of interest, leaving little independent variation for the instruments to detect. As a robustness check of the results, models were also tested that exclude the state dummies and include instead a series of broader area indicators, each representing one of the nine census divisions of the country. As expected, the predictive power of the instruments typically improve in these specifications, however, the overall conclusions of this paper remain unchanged (results available upon request).

\section{RESULTS}

Mandated benefit laws

Figure 1 shows the U.S. suicide rate for all adults ages 25-64. This figure shows a distinct downward trend over time in the suicide rate. Figure 2 shows the suicide rates over time in four states. The rates in Maryland and Minnesota, which have mental health mandated benefits on parity with physical health, are compared to the rates in Iowa and Michigan, which had not enacted any mental health mandated benefits as of 2000. The laws in Maryland and Minnesota are considered to be very comprehensive. These laws in these states apply to all types of mental illnesses, have no small business or cost increase exemptions, and include substance abuse treatment. Figure 2 shows that both Maryland and Minnesota experienced downward trends in the suicide rates after the enactment of the mental health parity laws, however, downward trends also existed during certain periods prior to the laws as well. Indeed, Michigan, which has no mental health benefit laws, experienced a downward trend throughout the entire 
1981-2000 period. Based on this simple picture, there is no suggestion that any decrease in the suicide rate can be attributed to the enactment of mental health parity laws. Thus, we proceed with a more formal, multivariate analysis.

The results in Table 2 show the effect of the adoption of any mental health insurance mandate (columns 1-3) and required mental health benefits (columns 4-6). In the OLS estimates presented in column 1, the effect of any mandate on the suicide rate is positive but not statistically significant. Once the endogeneity of mandate adoption is accounted for through the use of instrumental variables, the results presented in columns 2 and 3 suggest that mental health mandates remain positively associated with the suicide rate. However, only one of the TSLS coefficients is statistically significant and this is only at the 10 percent level (column 2 ). The instruments prove to be reliable. (First stage results are presented in Appendix Table 1.) The diabetes mandate indicator is a statistically significant predictor of mental health mandates, as is the percent of Republicans in the state's lower house. The F-statistics show that the instruments are statistically significant, and the magnitudes are fairly large. This indicates that it is unlikely that the models suffer from the problems of weak instruments. ${ }^{5}$ In column 3 , the overidentification statistic implies that the three instruments are appropriately excluded from the second stage equation and are not directly related to the suicide rate. Interestingly, the Hausman tests in columns 2 and 3 cannot reject the consistency of the OLS estimates, therefore, we conclude that the OLS results are trustworthy and the mandated benefit laws do not appear to be endogenous to the suicide rates.

In the models shown in columns 4-6 of Table 2, the mandate indicator takes the value of one when a mental health benefit must be provided (the required mental health benefit indicator).

\footnotetext{
${ }^{5}$ Bound et al. (1995) and others have noted that a low first stage F-statistic for the identifying instrumental variables may suggest that the TSLS estimates are no better than biased OLS estimates.
} 
Although the OLS estimate of the mandate coefficient is positive, it is small and statistically insignificant. The TSLS estimates shown in columns 5 and 6 are negative, but again, are not statistically significant at conventional levels. These TSLS results are not trustworthy as the Fstatistics on the instruments are not statistically significant, indicating the instruments are extremely weak predictors of required mandated benefits. As a result, the Hausman test statistics can not be trusted, and provide little guidance as to whether or not this measure of mandated benefits is endogenous.

Table 3 presents regression results where the mandate indicator takes the value of one only in instances where mental health benefits must be provided on parity with physical health. The models in columns 1-3 include the same covariates and instruments as those in the previous table. Unfortunately, as a result of extremely weak instruments, the TSLS results in columns 2 and 3 cannot be trusted (first stage results are presented in columns 1 and 2 of Appendix Table 2). Here, the F-statistics on the instruments are not statistically significant at conventional levels. The lack of predictive power in the first stage may result from the fact that no state enacted a mental health parity law prior to 1993, meaning that the parity law takes on a value of zero for all states in 12 years or in at least 60 percent of the observations. In an attempt to improve the predictive power of the instruments, the models shown in columns 4-6 are estimated based on a sample that is limited to the years 1993-2000, the time period in which states began passing parity laws. Here again, the OLS and TSLS estimates of the impact of the parity law on suicide rates are not statistically significant, although limiting the sample improves the first stage results. The instruments are statistically significant predictors of the passage of parity laws (columns 5 and 6), the overidentification restrictions are valid (column 6), while the Hausman test does not reject the consistency of OLS (columns 5 and 6). These results suggest that no relationship 
exists between parity laws and the adult suicide rate.

The measures of the mental health mandates used in Tables 2 and 3 are dichotomous indicators representing the presence or absence of certain mandates. An alternative way to present these results is to treat the mandates as mutually exclusive categories. The models shown in Table 4 include three indicators of the different types of mandates. As discussed above, we caution that these groupings are somewhat arbitrary and that the actual influence of the laws will depend tremendously on the details of the laws and the policies of regulatory agencies within the state. Subject to this caveat, mandate 1 represents states with mandated offerings only, mandate 2 represents states with mandated benefits that are not required to be on parity with physical health, and mandate 3 represents states with mandated benefits that are on parity with physical health. The omitted category represents states with no mandates.

Ordinary least squares and TSLS models are presented for the full sample (columns 1 and 2) and the sample limited to the years 1993-2000 (columns 3 and 4). All three available instruments are used in order to achieve identification. The discussion of the results in this table focuses on the OLS estimates since the statistics related to the TSLS estimates show that the instruments are valid (although their predictive power is very low in some cases), and the consistency of OLS cannot be rejected. The results uniformly show that mandates 1 and 3 are not statistically significant predictors of suicide rates, and the OLS magnitudes are small with the sign varying depending on the sample used. By contrast, mandate 2, which represents required benefits that are not on parity with physical health, is positively related to the suicide rates in the OLS models spanning all years. Here, the suicide rate in states having such a mandate is actually higher by almost 1 person per 100,000. This results may be indicative of the displacement effect of insurance mandates where increased costs induce 
individuals and businesses to drop coverage. When the sample is limited to 1993-2000, the effect of the required benefits remains positive, but is smaller and not longer statistically significant.

\section{State Characteristics}

Overall, mandated benefit laws appear to have no influence on adult suicide rates. The results in Tables 2-4 do show that some of the other state characteristics may help explain some of the variation in suicide rates across the full sample period. For example, labor market characteristics and economic conditions may predict suicide rates. Higher rates of female labor force participation are positively associated with suicides, as are higher unemployment rates. Per capita income, however, appears to have little effect as the magnitude of the coefficients are extremely small and are statistically insignificant in models utilizing the full sample period, although the coefficients are negative and statistically significant in models using the 1993-2000 period. In addition, states with larger percentages of the population with college degrees tend to have lower suicide rates.

The number of psychiatrists per 100,000 population is positively associated with the suicide rate. As discussed above, the interpretation of this result must be taken with caution as it is likely that the observed numbers of psychiatrists reflects the overall mental health status of the state population. Next, larger percentages of the population without health insurance are associated with lower suicide rates. The negative effect of uninsurance on suicide rates might arise if self-selection is present and people who do not buy insurance are a relatively healthy group. For example, self-employed individuals are much more likely than wage-earners to be uninsured, yet Perry and Rosen $(2001,2003)$ find no discernable differences between these two 
groups in regards to physical health status, mental health status, and service utilization. Lastly, larger percentages of the population on Medicaid are associated with higher suicide rates, A positive effect may arise if the program fails to provide the level of access to care necessary to prevent suicides among this population, however, it is also likely that this effect may simply reflect a time-varying state level characteristic such as lower levels of income among the state population.

\section{CONCLUSION}

This paper examines the potential for mental health insurance mandates to improve the mental health of the population as represented by the adult suicide rate. Using three different measures of mental health mandates, the results suggest that mandates do little to reduce the suicide rate. One of the primary difficulties in estimating the effects of mandated benefit laws on health outcomes is the potential endogenity of the laws. Previous research has shown that mental health parity laws are more likely to be enacted in states with lower mental health utilization and presumably better mental health status. Our research tests for such endogeneity, but finds little support for this claim when suicide rates are considered.

Using OLS and TSLS, the estimates employing the most general definition of what constitutes a mental health insurance mandate provide the most convincing and most robust results. Indeed, there appears to be no statistically significant relationship between mandate adoption and adult suicides. Partitioning the mandates into different categories provides a check on the robustness of this result. Mandated offering laws and parity laws, which represent the majority of the different types of state laws, drive the overall results and each appear to have no effect on suicide rates. However, the presence of mandated benefits that are not on parity with 
physical health benefits might increase the suicide rate. This result is consistent with a displacement effect of mandates.

This study contributes to the growing consensus in the literature that mental health mandates do not accomplish their desired goals. However, this research suffers from the problem of weak instruments with respect to some specific mandate classifications. Another limitation of this research is that the outcome studied includes individuals who are not affected by mental health mandates, which could bias the results toward zero. Despite these limitations, this research provides no evidence that mental health mandates reduce suicide rates. At best, these mandates have no effect on this outcome.

This research raises many interesting questions. A next step for research is to examine why these laws are not achieving improvements in mental health outcomes. This paper points to a number of possibilities. The design of the laws themselves might ensure no impact. In states like Arizona and Kentucky, where minimum mental health benefits are required only if the plan provides any mental health benefits, firms and insurance companies have the incentive and the option to drop benefits if they are too costly. Similarly, cost increase exemptions and small employer exemptions in a number of the state laws might prevent any of the mandates from being binding. The design of the laws notwithstanding, it is also unclear what impact the mandates have on the cost of providing mental and even physical health insurance. Rising premiums might encourage employers to raise employee contributions or to drop coverage altogether. These questions are beyond the scope of this study, but are nonetheless important questions in determining whether mandated mental health benefits improve the mental health of the population. 


\section{REFERENCES}

Angrist J.D. and A.B. Krueger (2001). "Instrumental Variables and the Search for Identification: From Supply and Demand to Natural Experiments" Journal of Economic Perspectives, $15(4), 69-85$.

Bound, J, Jaeger, DA, Baker, RM. (1995) "Problems With Instrumental Variables Estimation when the Correlation between the Instruments and the Endogenous Explanatory Variables is Weak." Journal of the American Statistical Association. 90:443-450.

Clark, DC and Horton-Deutsch SL. (1992) "Assessment in Absentia: The Value of the Psychological Autopsy Method for Studying Antecedents of Suicide and Predicting Future Suicides" in Maris RW, Berman AL, Maltsberger JT, and Yufit, RI (Eds) Assessment and Prediction of Suicide, New York: The Guilford Press.

Cutler D, Glaeser EL, and Norberg KE (2001). "The Economic Approach to Teenage Suicide" in Gruber J, (ed) Risky Behavior Among Youths. Chicago, IL: The University of Chicago Press.

Economic Report of the President (1991). United States Government Printing Office, Washington, D.C.

Egelko, S., M. Galanter, H. Dermatis, E. Jurewicz, A. Jamison, S. Dingle, and G. De Leon (2002). "Improved Psychological Status in a Modified Therapeutic Community for Homeless MICA Men.” Journal of Addictive Diseases, 21(2): 75-92.

Employee Benefits Research Institute (April 2000). "Employment-Based Health Care Benefits and Self-Funded Employment-Based Plans: An Overview." EBRI, Washington, DC.

England, Mary (1999). “Capturing Mental Health Care Offsets.” Health Affairs 18(2): 91-93.

Frank, Richard (1985). "Price and Location of Physician Services in Mental Health" Economic Inquiry 23(115): 115-133.

Frank, Richard and Thomas McGuire (2000). "Economics and Mental Health" in Culyer AJ and JP Newhouse, editors, Handbook of Health Economics, Volume 1B. Elsevier Science: Amsterdam.

Frank, Richard, Howard Goldman, and Thomas McGuire (2001). "Will Parity in Coverage Result in Better Mental Health Care?" The New England Journal of Medicine, 345(23): 1701-1704.

General Accounting Office (2000). "Mental Health Parity Act: Despite New Federal Standards, Mental Health Benefits Remain Limited.” HEHS-00-95: May 10.

Goldsmith, SK, TC Pellmar, AM Kleinman, and WE Bunney, (Eds) (2002). Reducing Suicide: 
A National Imperative. The National Academy Press: Washington DC.

Grossman, M. (1972) The Demand for Health: A Theoretical and Empirical Investigation. New York: Columbia University Press for the National Bureau of Economic Research.

Gruber, Jonathan (1994). "State-Mandated Benefits and Employer-Provided Health Insurance." The Journal of Public Economics, 55(3): 433-464.

Hall, WD, Mant, A, Mitchell, PB, Rendle, VA, Hickie, IB, and McManus, P (2003).

"Association Between Antidepressant Prescribing and Suicide in Australia, 1991-2000:

Trend Analysis" British Medical Journal, 326:1008-11.

Havassy, B, and P. Arns (1998). "Relationship of Cocaine and Other Substance Dependence to Well-Being of High-Risk Psychiatric Patients." Psychiatric Services, 49(7): 935-940.

Horgan, CM (1986). "The Demand for Ambulatory Mental Health Services from Specialty Providers" Health Services Research, 21(2): 291-319.

Kaestner, Robert and Kosali Simon (2002). "Labor Market Consequences of State Health Insurance Regulation.” Industrial and Labor Relations Review, 56(1): 136-159.

Maltsberger, JT (1992) "The Psychodynamic Formulation: An Aid in Assessing Suicide Risk" in Maris RW, Berman AL, Maltsberger JT, and Yufit, RI (Eds) Assessment and Prediction of Suicide, New York: The Guilford Press.

Maris RW, Berman AL, Maltsberger JT, and Yufit, RI (Eds) (1992) Assessment and Prediction of Suicide, New York: The Guilford Press.

Markowitz, S., P. Chatterji and R. Kaestner (2003) "Estimating the Impact of Alcohol Policies on Youth Suicides" Journal of Mental Health Policy and Economics 6: 37-46.

McGuire, TG and J Montgomery (1982). "Mandated Mental Health Benefits in Privat Health Insurance Policies" Journal of Health Politics, Policy and Law 7(2): 380-406.

Murphy, C.E. (1992). Suicide in Alcoholism. New York: Oxford University Press.

Murray, C. J. L., and A.D. Lopez, (Eds.) (1996). The global burden of disease. A comprehensive assessment of mortality and disability from diseases, injuries, and risk factors in 1990 and projected to 2020. Cambridge, MA: Harvard School of Public Health.

National Conference of State Legislatures (June 2003). State Laws Mandating or Regulating Mental Health Benefits. Retreived June 2003 from NCLS on the World Wide Web: http://www.ncsl.org/programs/health/mentalben.htm.

Olfson, M., M. Sing, and H. Schlesinger (1999). "Mental Health/Medical Care Cost Offsets: Opportunities for Managed Care." Health Affairs 18(2): 79-90. 
Pacula, Rosalie and Roland Sturm (2000). "Mental Health Parity Legislation: Much Ado About Nothing?" Health Services Research, 35(1): 263-275.

Perry, C.W. and H.S. Rosen (2001). "The Self-Employed Are Less Likely Than Wage-Earners to Have Health Insurance. So What?” NBER working paper \#8316.

Perry, C.W. and H.S. Rosen (2003). "Insurance and the Utilization of Medical Services Among the Self-Employed," in S Cnossen and HW Sinn (eds), Public Finances and Public Policy in the New Century. Mit Press: Cambridge, MA.

Simon, GE and M. Von Korff (1998). "Suicide Mortality Among Patients Treated for Depression in an Insured Population" American Journal of Epidemiology, 147(2), 155160.

Sturm, Roland. "State Parity Legislation and Changes in Health Insurance and Perceived Access to Care Among Individual with Mental Illness: 1996-1998." Journal of Mental Health Policy and Economics 3 (2000): 209-13.

Sturm, Roland and Rosalie Pacula (1999). "State Mental Health Parity Laws: Cause or Consequence of Differences in Use?" Health Affairs, 18(5): 182-192.

Substance Abuse and Mental Health Services Administration (1999). Effects of the Mental Health Parity Act of 1996. Rockville, Md.: U.S. Department of Health and Human Services.

U.S. Department of Health and Human Services (1999). Mental Health: A Report of the Surgeon General-Executive Summary. Rockville, MD: U.S. Department of Health and Human Services, Substance Abuse and Mental Health Services Administration, Center for Mental Health Services, National Institutes of Health, National Institute of Mental Health, 1999.

Zuvekas, Samuel, Darrel Regier, Donald Rae, Agnes Rupp, and William Narrow (2002). "The Impacts of Mental Health Parity and Managed Care in One Large Employer Group." Health Affairs, 21(3): 148-159. 
Figure 1

U.S. Suicide Rate, Adults ages 25-64

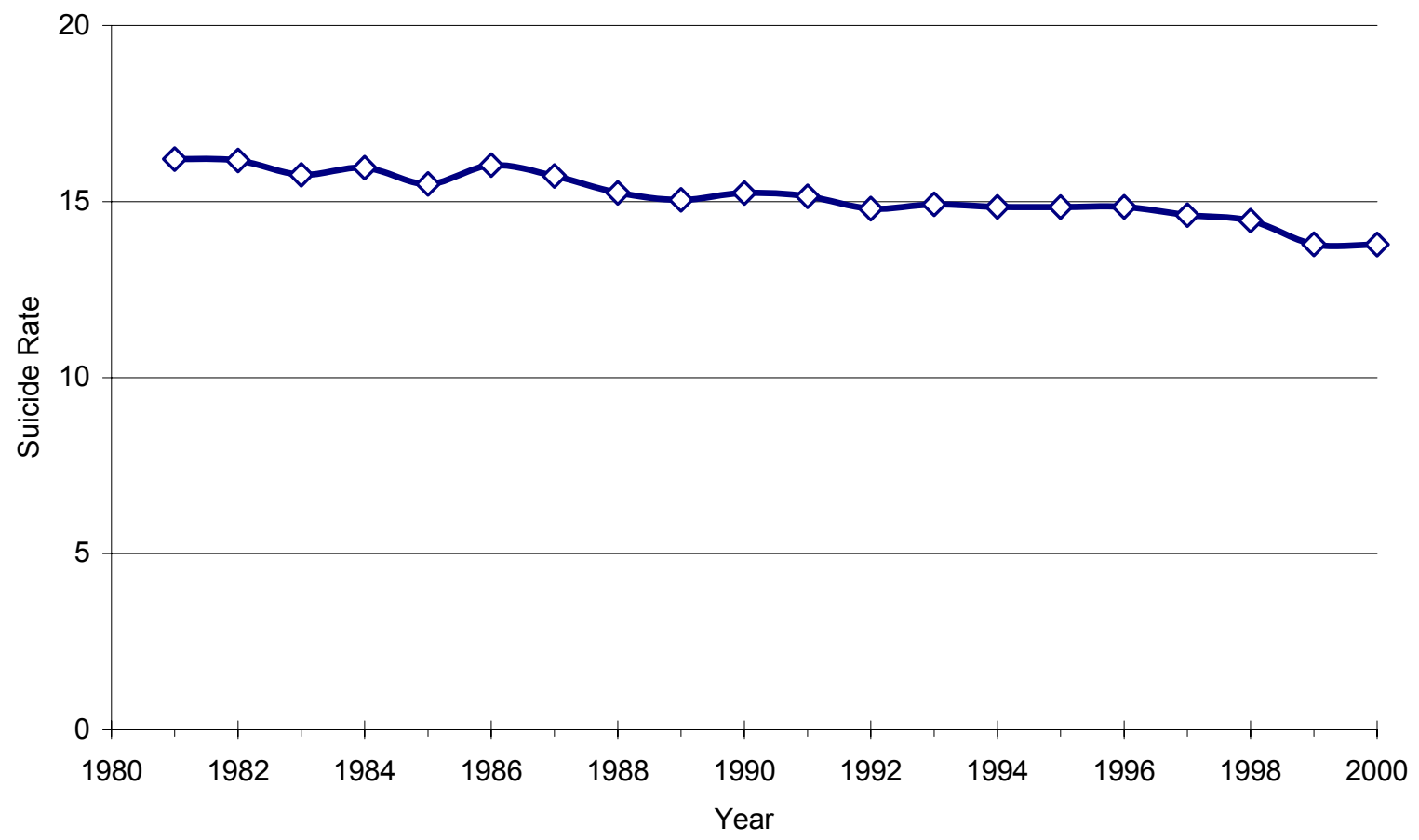

Figure 2

Suicide Rates, Selected States, Adults ages 25-64

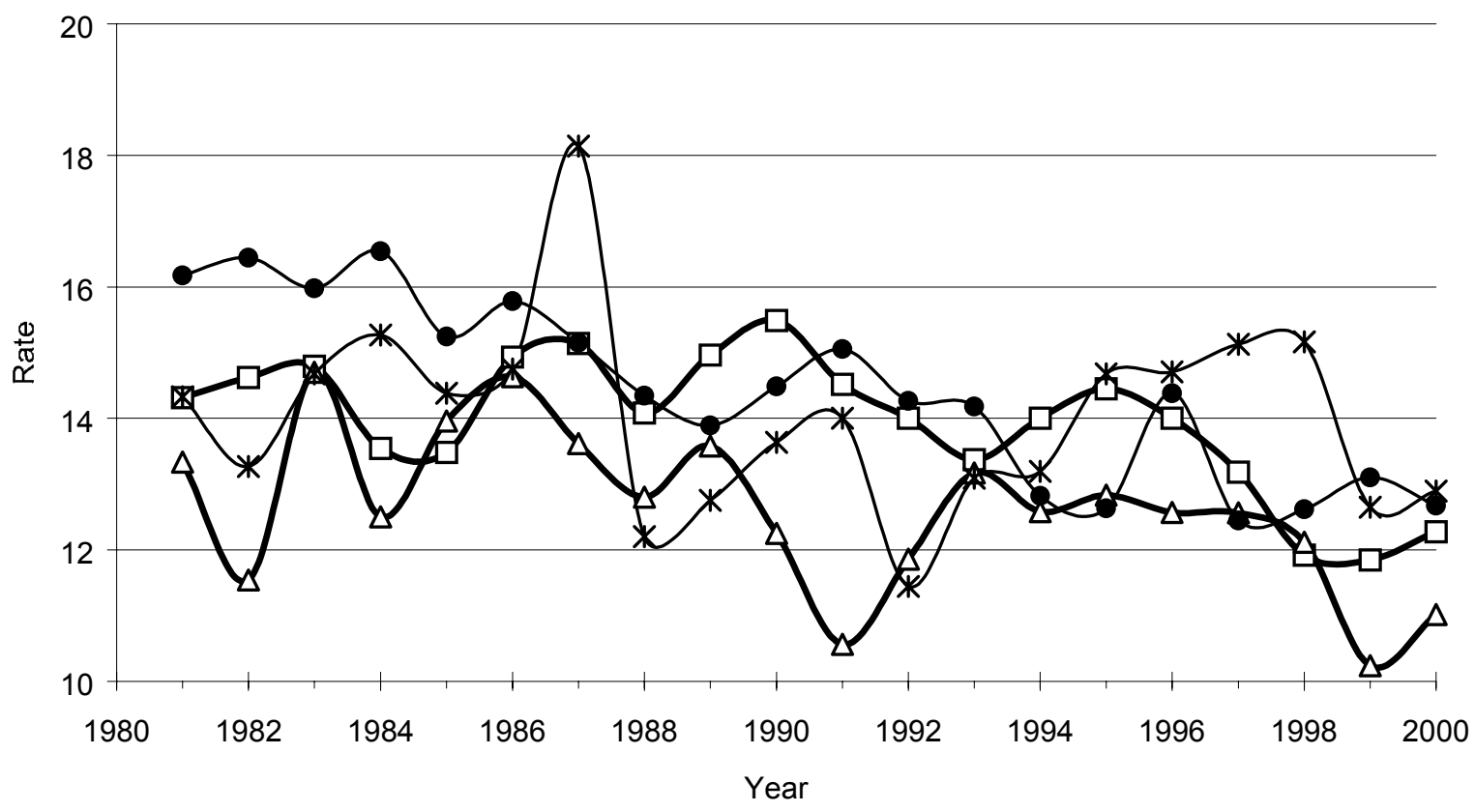

$\neg-$ Minnesota: Parity $1995 \longrightarrow$ Maryland: Parity $1994 \rightarrow$ lowa: No law $\rightarrow-$ Michigan: No law 
Table 1

Summary Statistics of Selected Variables

\begin{tabular}{|c|c|c|c|c|}
\hline Variable & Definition & Mean & Std Dev & Source \\
\hline Adult suicide rate & $\begin{array}{l}\text { Number of adult suicides ages } 25-64 \text {, per } 100,000 \\
\text { population ages } 25-64\end{array}$ & 16.41 & 4.16 & NCHS \\
\hline $\begin{array}{l}\text { Any mental health } \\
\text { mandate }\end{array}$ & $\begin{array}{l}\text { Indicator }=1 \text { if state has some form of a mental } \\
\text { health insurance mandate in place, including parity } \\
\text { mandate, benefit mandate, or offering mandate }\end{array}$ & 0.27 & 0.44 & $\begin{array}{l}\text { NCSL and } \\
\text { state statutes }\end{array}$ \\
\hline $\begin{array}{l}\text { Required mental } \\
\text { health benefit }\end{array}$ & $\begin{array}{l}\text { Indicator }=1 \text { if state mandates health insurance } \\
\text { plans to provide mental health benefits. May or } \\
\text { may not be on parity with physical health benefits }\end{array}$ & 0.11 & 0.31 & $\begin{array}{l}\text { NCSL and } \\
\text { state statutes }\end{array}$ \\
\hline Parity & $\begin{array}{l}\text { Indicator }=1 \text { if state mandates health insurance } \\
\text { plans to provide mental health benefits on parity } \\
\text { with physical health }\end{array}$ & 0.06 & 0.24 & $\begin{array}{l}\text { NCSL and } \\
\text { state statutes }\end{array}$ \\
\hline $\begin{array}{l}\text { Labor force } \\
\text { participation }\end{array}$ & Labor force participation rate of women & 58.26 & 5.20 & BLS \\
\hline Unemployment & Unemployment rate & 6.05 & 2.20 & BLS \\
\hline Real income & Per capita income adjusted for inflation & 140.32 & 24.20 & BEA \\
\hline Percent rural & Percent of state population living in rural areas & 31.07 & 14.59 & Census \\
\hline College degree & $\begin{array}{l}\text { Percent of state population ages } 25 \text { years and older } \\
\text { that has graduated from a } 4 \text {-year college }\end{array}$ & 20.38 & 4.65 & Census \\
\hline Percent black & Percent of state population black & 9.64 & 9.22 & Census \\
\hline Beer tax & State excise tax on beer & 0.51 & 0.19 & Beer Institute \\
\hline Psychiatrists & Number of psychiatrists per 100,000 population & 21.46 & 9.77 & AMA \\
\hline $\begin{array}{l}\text { Percent large } \\
\text { employers }\end{array}$ & $\begin{array}{l}\text { Percent of state workforce in firms with } 500+ \\
\text { employees }\end{array}$ & 33.08 & 14.88 & SBA \\
\hline Percent uninsured & Percent of state population with no health insurance & 16.34 & 4.73 & CPS \\
\hline Percent Medicaid & Percent of state population with Medicaid & 8.73 & 3.47 & CPS \\
\hline Diabetes law & $\begin{array}{l}\text { Indicator }=1 \text { if state has mandate requiring insurers } \\
\text { to cover diabetes treatments }\end{array}$ & 0.17 & 0.38 & NCSL \\
\hline $\begin{array}{l}\text { Congressional } \\
\text { Republicans }\end{array}$ & $\begin{array}{l}\text { Percent of congressional delegation affiliated with } \\
\text { Republican Party }\end{array}$ & 0.48 & 0.29 & STAT AB \\
\hline State Republicans & Percent of Republicans in state lower house & 0.44 & 0.17 & STAT AB \\
\hline
\end{tabular}

AMA: American Medical Association

BLS: Bureau of Labor Statistics, U.S. Department of Labor

BEA: Bureau of Economic Analysis, U.S. Department of Commerce

Census: U.S. Bureau of the Census

CPS: Current Population Survey, BLS and Bureau of the Census

NCHS: National Center for Health Statistics, Centers for Disease Control

NCSL: National Conference of State Legislatures

STAT AB: Statistical Abstract

SBA: U.S. Small Business Administration 
Table 2

OLS and TSLS Regressions

Adult Suicides and Mental Health Benefits

\begin{tabular}{|c|c|c|c|c|c|c|}
\hline & $\begin{array}{l}\text { OLS } \\
(1) \\
\end{array}$ & $\begin{array}{c}\text { TSLS } \\
(2) \\
\end{array}$ & $\begin{array}{c}\text { TSLS } \\
(3) \\
\end{array}$ & $\begin{array}{c}\text { OLS } \\
(4)\end{array}$ & $\begin{array}{c}\text { TSLS } \\
(5) \\
\end{array}$ & $\begin{array}{l}\text { TSLS } \\
(6) \\
\end{array}$ \\
\hline Any mental health mandate & $\begin{array}{r}0.012 \\
(0.09)\end{array}$ & $\begin{array}{l}2.530 \\
(1.80)\end{array}$ & $\begin{array}{l}0.905 \\
(1.05)\end{array}$ & & & \\
\hline $\begin{array}{l}\text { Required mental health } \\
\text { benefit }\end{array}$ & & & & $\begin{array}{r}0.119 \\
(0.61)\end{array}$ & $\begin{array}{c}-11.141 \\
(-0.98)\end{array}$ & $\begin{array}{r}-11.869 \\
(-1.01)\end{array}$ \\
\hline Labor force participation & $\begin{array}{r}0.162 \\
(5.32)\end{array}$ & $\begin{array}{l}0.135 \\
(3.48)\end{array}$ & $\begin{array}{r}0.153 \\
(4.69)\end{array}$ & $\begin{array}{r}0.164 \\
(5.36)\end{array}$ & $\begin{array}{c}0.058 \\
(0.47)\end{array}$ & $\begin{array}{r}0.052 \\
(0.40)\end{array}$ \\
\hline Unemployment & $\begin{array}{r}0.119 \\
(2.89)\end{array}$ & $\begin{array}{l}0.126 \\
(2.60)\end{array}$ & $\begin{array}{r}0.122 \\
(2.87)\end{array}$ & $\begin{array}{l}0.118 \\
(2.85)\end{array}$ & $\begin{array}{l}0.248 \\
(1.56)\end{array}$ & $\begin{array}{l}0.256 \\
(1.56)\end{array}$ \\
\hline Real income & $\begin{array}{l}-0.009 \\
(-1.02)\end{array}$ & $\begin{array}{l}-0.008 \\
(-0.79)\end{array}$ & $\begin{array}{l}-0.009 \\
(-0.96)\end{array}$ & $\begin{array}{l}-0.010 \\
(-1.06)\end{array}$ & $\begin{array}{l}0.020 \\
(0.56)\end{array}$ & $\begin{array}{l}0.022 \\
(0.59)\end{array}$ \\
\hline Percent rural & $\begin{array}{r}0.033 \\
(0.91)\end{array}$ & $\begin{array}{r}0.023 \\
(0.54)\end{array}$ & $\begin{array}{r}0.029 \\
(0.79)\end{array}$ & $\begin{array}{r}0.031 \\
(0.87)\end{array}$ & $\begin{array}{c}0.171 \\
(1.06)\end{array}$ & $\begin{array}{r}0.180 \\
(1.08)\end{array}$ \\
\hline College degree & $\begin{array}{l}-0.081 \\
(-2.10)\end{array}$ & $\begin{array}{l}-0.108 \\
(-2.28)\end{array}$ & $\begin{array}{l}-0.090 \\
(-2.24)\end{array}$ & $\begin{array}{l}-0.081 \\
(-2.10)\end{array}$ & $\begin{array}{c}-0.042 \\
(-0.46)\end{array}$ & $\begin{array}{r}-0.040 \\
(-0.41)\end{array}$ \\
\hline Percent black & $\begin{array}{r}0.314 \\
(3.02)\end{array}$ & $\begin{array}{l}0.118 \\
(0.72)\end{array}$ & $\begin{array}{r}0.244 \\
(1.95)\end{array}$ & $\begin{array}{r}0.313 \\
(3.02)\end{array}$ & $\begin{array}{c}0.503 \\
(1.71)\end{array}$ & $\begin{array}{l}0.516 \\
(1.68)\end{array}$ \\
\hline Beer tax & $\begin{array}{r}0.476 \\
(0.55)\end{array}$ & $\begin{array}{l}1.301 \\
(1.17)\end{array}$ & $\begin{array}{r}0.769 \\
(0.83)\end{array}$ & $\begin{array}{r}0.418 \\
(0.48)\end{array}$ & $\begin{array}{r}5.533 \\
(1.00)\end{array}$ & $\begin{array}{r}5.863 \\
(1.03)\end{array}$ \\
\hline Psychiatrists & $\begin{array}{r}0.295 \\
(8.69)\end{array}$ & $\begin{array}{c}0.294 \\
(7.43)\end{array}$ & $\begin{array}{r}0.295 \\
(8.49)\end{array}$ & $\begin{array}{r}0.295 \\
(8.68)\end{array}$ & $\begin{array}{r}0.325 \\
(4.12)\end{array}$ & $\begin{array}{r}0.327 \\
(3.96)\end{array}$ \\
\hline Percent large employers & $\begin{array}{l}-0.016 \\
(-0.77)\end{array}$ & $\begin{array}{l}-0.046 \\
(-1.56)\end{array}$ & $\begin{array}{l}-0.027 \\
(-1.13)\end{array}$ & $\begin{array}{r}-0.017 \\
(-0.83)\end{array}$ & $\begin{array}{r}0.105 \\
(0.80)\end{array}$ & $\begin{array}{c}0.113 \\
(0.83)\end{array}$ \\
\hline Percent uninsured & $\begin{array}{l}-0.068 \\
(-2.92)\end{array}$ & $\begin{array}{l}-0.072 \\
(-2.64)\end{array}$ & $\begin{array}{l}-0.069 \\
(-2.91)\end{array}$ & $\begin{array}{l}-0.067 \\
(-2.89)\end{array}$ & $\begin{array}{c}-0.140 \\
(-1.57)\end{array}$ & $\begin{array}{l}-0.145 \\
(-1.57)\end{array}$ \\
\hline Percent Medicaid & $\begin{array}{r}0.059 \\
(2.31)\end{array}$ & $\begin{array}{c}0.064 \\
(2.16)\end{array}$ & $\begin{array}{r}0.061 \\
(2.33)\end{array}$ & $\begin{array}{r}0.060 \\
(2.34)\end{array}$ & $\begin{array}{r}-0.017 \\
(-0.18)\end{array}$ & $\begin{array}{l}-0.022 \\
(-0.22)\end{array}$ \\
\hline R-squared & 0.903 & 0.868 & 0.898 & 0.903 & 0.554 & 0.507 \\
\hline Overidentification test & & & $\begin{array}{c}4.349 \\
{[0.114]}\end{array}$ & & & $\begin{array}{c}0.103 \\
{[0.950]}\end{array}$ \\
\hline Hausman test & & $\begin{array}{c}3.239 \\
{[0.072]}\end{array}$ & $\begin{array}{c}1.100 \\
{[0.294]}\end{array}$ & & $\begin{array}{c}0.981 \\
{[0.322]}\end{array}$ & $\begin{array}{c}1.041 \\
{[0.308]}\end{array}$ \\
\hline F-test on instrument(s) & & $\begin{array}{l}12.370 \\
{[0.000]}\end{array}$ & $\begin{array}{c}8.620 \\
{[0.000]}\end{array}$ & & $\begin{array}{c}1.250 \\
{[0.265]}\end{array}$ & $\begin{array}{c}0.430 \\
{[0.731]}\end{array}$ \\
\hline
\end{tabular}

Note: t-statistics in parentheses, p-values in brackets, and intercept not shown. All models include state and year dummies. $N=1,000$. The instrument in columns 2 and 5 is the diabetes mandate. The instruments in columns 3 and 6 are the diabetes mandate, the percent of Republicans in state lower house, and the percent of the state's congressional delegation Republican. 
Table 3

OLS and TSLS Regressions

Adult Suicides and Mental Health Parity

\begin{tabular}{|c|c|c|c|c|c|c|}
\hline & $\begin{array}{c}\text { OLS } \\
(1)\end{array}$ & $\begin{array}{c}\text { TSLS } \\
\text { (2) } \\
\end{array}$ & $\begin{array}{c}\text { TSLS } \\
\text { (3) }\end{array}$ & $\begin{array}{c}\text { OLS } \\
(4)\end{array}$ & $\begin{array}{c}\text { TSLS } \\
(5) \\
\end{array}$ & $\begin{array}{l}\text { TSLS } \\
(6) \\
\end{array}$ \\
\hline & All years & All years & All years & $1993-2000$ & $1993-2000$ & $1993-2000$ \\
\hline$\overline{\text { Parity }}$ & $\begin{array}{c}-0.305 \\
(-1.50)\end{array}$ & $\begin{array}{c}-13.057 \\
(-0.91)\end{array}$ & $\begin{array}{c}-10.721 \\
(-1.12)\end{array}$ & $\begin{array}{c}-0.081 \\
(-0.37)\end{array}$ & $\begin{array}{r}2.465 \\
(1.29)\end{array}$ & $\begin{array}{r}0.503 \\
(0.62)\end{array}$ \\
\hline Labor force participation & $\begin{array}{r}0.157 \\
(5.11)\end{array}$ & $\begin{array}{c}-0.081 \\
(-0.29)\end{array}$ & $\begin{array}{c}-0.037 \\
(-0.20)\end{array}$ & $\begin{array}{c}0.038 \\
(0.74)\end{array}$ & $\begin{array}{c}0.106 \\
(1.34)\end{array}$ & $\begin{array}{r}0.053 \\
(0.96)\end{array}$ \\
\hline Unemployment & $\begin{array}{c}0.122 \\
(2.94)\end{array}$ & $\begin{array}{r}0.207 \\
(1.53)\end{array}$ & $\begin{array}{r}0.191 \\
(1.85)\end{array}$ & $\begin{array}{r}0.450 \\
(3.74)\end{array}$ & $\begin{array}{c}0.488 \\
(3.35)\end{array}$ & $\begin{array}{r}0.459 \\
(3.75)\end{array}$ \\
\hline Real income & $\begin{array}{c}-0.008 \\
(-0.84)\end{array}$ & $\begin{array}{c}0.059 \\
(0.76)\end{array}$ & $\begin{array}{r}0.047 \\
(0.88)\end{array}$ & $\begin{array}{c}-0.066 \\
(-3.30)\end{array}$ & $\begin{array}{c}-0.113 \\
(-2.68)\end{array}$ & $\begin{array}{c}-0.077 \\
(-3.10)\end{array}$ \\
\hline Percent rural & $\begin{array}{r}0.035 \\
(0.97)\end{array}$ & $\begin{array}{c}0.111 \\
(0.93)\end{array}$ & $\begin{array}{r}0.097 \\
(1.07)\end{array}$ & $\begin{array}{c}-0.058 \\
(-0.76)\end{array}$ & $\begin{array}{c}-0.081 \\
(-0.88)\end{array}$ & $\begin{array}{c}-0.064 \\
(-0.82)\end{array}$ \\
\hline College degree & $\begin{array}{c}-0.077 \\
(-2.01)\end{array}$ & $\begin{array}{r}0.052 \\
(0.31)\end{array}$ & $\begin{array}{r}0.028 \\
(0.23)\end{array}$ & $\begin{array}{r}-0.029 \\
(-0.67)\end{array}$ & $\begin{array}{c}-0.069 \\
(-1.17)\end{array}$ & $\begin{array}{c}-0.038 \\
(-0.84)\end{array}$ \\
\hline Percent black & $\begin{array}{r}0.320 \\
(3.09)\end{array}$ & $\begin{array}{r}0.525 \\
(1.58)\end{array}$ & $\begin{array}{r}0.487 \\
(1.91)\end{array}$ & $\begin{array}{c}0.430 \\
(2.05)\end{array}$ & $\begin{array}{c}0.310 \\
(1.17)\end{array}$ & $\begin{array}{c}0.402 \\
(1.87)\end{array}$ \\
\hline Beer tax & $\begin{array}{r}0.543 \\
(0.62)\end{array}$ & $\begin{array}{r}3.474 \\
(0.90)\end{array}$ & $\begin{array}{r}2.937 \\
(1.05)\end{array}$ & $\begin{array}{r}2.307 \\
(0.57)\end{array}$ & $\begin{array}{c}-1.791 \\
(-0.31)\end{array}$ & $\begin{array}{r}1.367 \\
(0.32)\end{array}$ \\
\hline Psychiatrists & $\begin{array}{r}0.299 \\
(8.78)\end{array}$ & $\begin{array}{c}0.434 \\
(2.54)\end{array}$ & $\begin{array}{r}0.409 \\
(3.36)\end{array}$ & $\begin{array}{c}0.176 \\
(2.13)\end{array}$ & $\begin{array}{c}0.193 \\
(1.95)\end{array}$ & $\begin{array}{r}0.180 \\
(2.15)\end{array}$ \\
\hline Percent large employers & $\begin{array}{c}-0.014 \\
(-0.70)\end{array}$ & $\begin{array}{c}0.048 \\
(0.57)\end{array}$ & $\begin{array}{r}0.037 \\
(0.59)\end{array}$ & $\begin{array}{c}-0.106 \\
(-1.48)\end{array}$ & $\begin{array}{c}-0.085 \\
(-0.97)\end{array}$ & $\begin{array}{c}-0.101 \\
(-1.39)\end{array}$ \\
\hline Percent uninsured & $\begin{array}{c}-0.068 \\
(-2.94)\end{array}$ & $\begin{array}{c}-0.078 \\
(-1.43)\end{array}$ & $\begin{array}{c}-0.076 \\
(-1.65)\end{array}$ & $\begin{array}{c}0.036 \\
(1.00)\end{array}$ & $\begin{array}{c}0.071 \\
(1.42)\end{array}$ & $\begin{array}{c}0.044 \\
(1.16)\end{array}$ \\
\hline Percent Medicaid & $\begin{array}{r}0.061 \\
(2.38)\end{array}$ & $\begin{array}{r}0.132 \\
(1.33)\end{array}$ & $\begin{array}{r}0.119 \\
(1.62)\end{array}$ & $\begin{array}{r}0.083 \\
(2.30)\end{array}$ & $\begin{array}{r}0.072 \\
(1.63)\end{array}$ & $\begin{array}{r}0.081 \\
(2.19)\end{array}$ \\
\hline R-squared & 0.903 & 0.487 & 0.625 & 0.942 & 0.919 & 0.941 \\
\hline Overidentification test & & & $\begin{array}{c}0.233 \\
{[0.890]}\end{array}$ & & & $\begin{array}{c}2.114 \\
{[0.348]}\end{array}$ \\
\hline Hausman test & & $\begin{array}{c}0.790 \\
{[0.374]}\end{array}$ & $\begin{array}{c}1.185 \\
{[0.276]}\end{array}$ & & $\begin{array}{c}1.799 \\
{[0.180]}\end{array}$ & $\begin{array}{c}0.559 \\
{[0.455]}\end{array}$ \\
\hline F-test on instrument(s) & & $\begin{array}{c}0.980 \\
{[0.324]}\end{array}$ & $\begin{array}{c}0.530 \\
{[0.663]}\end{array}$ & & $\begin{array}{c}6.250 \\
{[0.013]}\end{array}$ & $\begin{array}{c}8.890 \\
{[0.000]}\end{array}$ \\
\hline
\end{tabular}

Note: t-statistics in parentheses, $p$-values in brackets, and intercept not shown. All models include state and year dummies. $\mathrm{N}=1,000$ in columns 1 and 2, N=400 in columns 3 and 4 . The instrument in columns 2 and 5 is the diabetes mandate. The instruments in columns 3 and 6 are the diabetes mandate, the percent of Republicans in state lower house, and the percent of the state's congressional delegation Republican. 
Table 4

OLS and TSLS Regressions

Adult Suicides and Mental Health Mandates Categories

\begin{tabular}{|c|c|c|c|c|}
\hline & $\begin{array}{c}\text { OLS } \\
(1) \\
\end{array}$ & $\begin{array}{c}\text { TSLS } \\
(2) \\
\end{array}$ & $\begin{array}{c}\text { OLS } \\
(3) \\
\end{array}$ & $\begin{array}{c}\text { TSLS } \\
(4) \\
\end{array}$ \\
\hline & All years & All years & 1993-2000 & 1993-2000 \\
\hline Mandate 1 & $\begin{array}{c}-0.089 \\
(-0.56)\end{array}$ & $\begin{array}{c}-0.676 \\
(-0.23)\end{array}$ & $\begin{array}{r}-0.017 \\
(-0.07)\end{array}$ & $\begin{array}{l}1.115 \\
(0.22)\end{array}$ \\
\hline Mandate 2 & $\begin{array}{r}0.961 \\
(2.96)\end{array}$ & $\begin{array}{c}-10.211 \\
(-0.34)\end{array}$ & $\begin{array}{r}0.477 \\
(1.28)\end{array}$ & $\begin{array}{l}-4.786 \\
(-0.88)\end{array}$ \\
\hline Mandate 3 & $\begin{array}{c}-0.171 \\
(-0.78)\end{array}$ & $\begin{array}{c}-15.584 \\
(-0.76)\end{array}$ & $\begin{array}{r}0.002 \\
(0.01)\end{array}$ & $\begin{array}{c}-0.679 \\
(-0.46)\end{array}$ \\
\hline Labor force participation & $\begin{array}{c}0.152 \\
(4.96)\end{array}$ & $\begin{array}{c}-0.019 \\
(-0.06)\end{array}$ & $\begin{array}{c}0.042 \\
(0.82)\end{array}$ & $\begin{array}{c}-0.020 \\
(-0.16)\end{array}$ \\
\hline Unemployment & $\begin{array}{r}0.115 \\
(2.78)\end{array}$ & $\begin{array}{r}0.264 \\
(1.07)\end{array}$ & $\begin{array}{c}0.434 \\
(3.55)\end{array}$ & $\begin{array}{r}0.555 \\
(1.14)\end{array}$ \\
\hline Real income & $\begin{array}{c}-0.006 \\
(-0.67)\end{array}$ & $\begin{array}{c}0.044 \\
(0.45)\end{array}$ & $\begin{array}{l}-0.063 \\
(-3.13)\end{array}$ & $\begin{array}{l}-0.101 \\
(-2.22)\end{array}$ \\
\hline Percent rural & $\begin{array}{r}0.027 \\
(0.75)\end{array}$ & $\begin{array}{r}0.186 \\
(0.67)\end{array}$ & $\begin{array}{r}-0.067 \\
(-0.87)\end{array}$ & $\begin{array}{r}0.032 \\
(0.24)\end{array}$ \\
\hline College degree & $\begin{array}{c}-0.072 \\
(-1.87)\end{array}$ & $\begin{array}{c}0.014 \\
(0.06)\end{array}$ & $\begin{array}{c}-0.024 \\
(-0.55)\end{array}$ & $\begin{array}{r}-0.083 \\
(-0.84)\end{array}$ \\
\hline Percent black & $\begin{array}{r}0.322 \\
(3.11)\end{array}$ & $\begin{array}{r}0.615 \\
(1.10)\end{array}$ & $\begin{array}{r}0.440 \\
(2.09)\end{array}$ & $\begin{array}{r}0.277 \\
(0.84)\end{array}$ \\
\hline Beer tax & $\begin{array}{r}0.227 \\
(0.26)\end{array}$ & $\begin{array}{r}5.817 \\
(0.64)\end{array}$ & $\begin{array}{l}1.890 \\
(0.45)\end{array}$ & $\begin{array}{l}10.375 \\
(0.45)\end{array}$ \\
\hline Psychiatrists & $\begin{array}{r}0.305 \\
(8.98)\end{array}$ & $\begin{array}{c}0.378 \\
(1.50)\end{array}$ & $\begin{array}{r}0.179 \\
(2.15)\end{array}$ & $\begin{array}{r}0.185 \\
(0.93)\end{array}$ \\
\hline Percent large employers & $\begin{array}{c}-0.021 \\
(-1.00)\end{array}$ & $\begin{array}{r}0.122 \\
(0.48)\end{array}$ & $\begin{array}{l}-0.104 \\
(-1.44)\end{array}$ & $\begin{array}{l}-0.123 \\
(-1.13)\end{array}$ \\
\hline Percent Uninsured & $\begin{array}{c}-0.062 \\
(-2.66)\end{array}$ & $\begin{array}{c}-0.133 \\
(-0.72)\end{array}$ & $\begin{array}{r}0.037 \\
(1.03)\end{array}$ & $\begin{array}{r}0.027 \\
(0.52)\end{array}$ \\
\hline Percent Medicaid & $\begin{array}{r}0.072 \\
(2.81)\end{array}$ & $\begin{array}{r}0.022 \\
(0.07)\end{array}$ & $\begin{array}{r}0.088 \\
(2.42)\end{array}$ & $\begin{array}{r}0.023 \\
(0.33)\end{array}$ \\
\hline $\begin{array}{l}\text { R-squared } \\
\text { Hausman test }\end{array}$ & 0.904 & $\begin{array}{c}0.328 \\
6.520 \\
{[0.089]}\end{array}$ & 0.943 & $\begin{array}{c}0.901 \\
3.921 \\
{[0.270]}\end{array}$ \\
\hline $\begin{array}{l}\text { F-test on instruments for } \\
\text { mandate } 1\end{array}$ & & $\begin{array}{l}13.080 \\
{[0.000]}\end{array}$ & & $\begin{array}{c}0.680 \\
{[0.566]}\end{array}$ \\
\hline $\begin{array}{l}\text { F-test on on instruments for } \\
\text { mandate } 2\end{array}$ & & $\begin{array}{c}0.290 \\
{[0.833]}\end{array}$ & & $\begin{array}{c}2.030 \\
{[0.109]}\end{array}$ \\
\hline $\begin{array}{l}\text { F-test on on instruments for } \\
\text { mandate } 3\end{array}$ & & $\begin{array}{c}0.530 \\
{[0.663]}\end{array}$ & & $\begin{array}{l}8.89 \\
{[0.000]}\end{array}$ \\
\hline
\end{tabular}

Note: t-statistics in parentheses, p-values in brackets, and intercept not shown. All models include state and year dummies. $\mathrm{N}=1,000$ in columns 1 and 2, $\mathrm{N}=400$ in columns 3 and 4 . The instruments in columns 2 and 4 are the diabetes mandate, the percent of Republicans in state lower house, and the percent of the state's congressional delegation Republican. Mandate 1 represents states with mandated offerings only. Mandate 2 represents states with mandated benefits that are not on parity with physical health. Mandate 3 represents states with mandated benefits that are on parity with physical health. The omitted category represents states with no mandates. 
Appendix Table 1

First Stage Regressions

\begin{tabular}{lcccc}
\hline & \multicolumn{2}{c}{ Any mental health mandate } & \multicolumn{2}{c}{ Required mental health } \\
benefit
\end{tabular}

Note: t-statistics in parentheses, and intercept not shown. $\mathrm{N}=1,000$. 
Appendix Table 2

First Stage Regressions

\begin{tabular}{|c|c|c|c|c|}
\hline & \multicolumn{2}{|c|}{$\begin{array}{c}\text { Parity } \\
1981-2000\end{array}$} & \multicolumn{2}{|c|}{$\begin{array}{c}\text { Parity } \\
1993-2000\end{array}$} \\
\hline & $(1)$ & $(2)$ & (3) & $(4)$ \\
\hline Diabetes Law & $\begin{array}{c}-0.024 \\
(-0.99)\end{array}$ & $\begin{array}{c}-0.024 \\
(-0.97)\end{array}$ & $\begin{array}{r}0.115 \\
(2.50)\end{array}$ & $\begin{array}{r}0.123 \\
(2.72)\end{array}$ \\
\hline Congress Republicans & & $\begin{array}{c}-0.036 \\
(-0.70)\end{array}$ & & $\begin{array}{r}0.006 \\
(0.05)\end{array}$ \\
\hline State Republicans & & $\begin{array}{c}-0.041 \\
(-0.29)\end{array}$ & & $\begin{array}{r}1.757 \\
(4.47)\end{array}$ \\
\hline Labor force participation & $\begin{array}{l}-0.019 \\
(-3.80)\end{array}$ & $\begin{array}{l}-0.019 \\
(-3.74)\end{array}$ & $\begin{array}{l}-0.025 \\
(-2.02)\end{array}$ & $\begin{array}{l}-0.026 \\
(-2.14)\end{array}$ \\
\hline Unemployment & $\begin{array}{r}0.007 \\
(1.03)\end{array}$ & $\begin{array}{c}0.008 \\
(1.11)\end{array}$ & $\begin{array}{c}-0.014 \\
(-0.45)\end{array}$ & $\begin{array}{c}-0.027 \\
(-0.91)\end{array}$ \\
\hline Real income & $\begin{array}{r}0.005 \\
(3.63)\end{array}$ & $\begin{array}{r}0.005 \\
(3.49)\end{array}$ & $\begin{array}{c}0.018 \\
(3.65)\end{array}$ & $\begin{array}{r}0.019 \\
(3.91)\end{array}$ \\
\hline Percent rural & $\begin{array}{r}0.005 \\
(0.90)\end{array}$ & $\begin{array}{c}0.005 \\
(0.89)\end{array}$ & $\begin{array}{c}0.024 \\
(1.20)\end{array}$ & $\begin{array}{c}0.012 \\
(0.59)\end{array}$ \\
\hline College degree & $\begin{array}{r}0.010 \\
(1.54)\end{array}$ & $\begin{array}{r}0.009 \\
(1.50)\end{array}$ & $\begin{array}{r}0.017 \\
(1.61)\end{array}$ & $\begin{array}{r}0.021 \\
(2.01)\end{array}$ \\
\hline Percent black & $\begin{array}{c}0.018 \\
(1.04)\end{array}$ & $\begin{array}{r}0.020 \\
(1.15)\end{array}$ & $\begin{array}{r}0.050 \\
(0.96)\end{array}$ & $\begin{array}{r}0.005 \\
(0.10)\end{array}$ \\
\hline Beer tax & $\begin{array}{c}0.236 \\
(1.68)\end{array}$ & $\begin{array}{c}0.209 \\
(1.40)\end{array}$ & $\begin{array}{c}1.380 \\
(1.36)\end{array}$ & $\begin{array}{r}2.561 \\
(2.50)\end{array}$ \\
\hline Psychiatrists & $\begin{array}{r}0.012 \\
(2.07)\end{array}$ & $\begin{array}{r}0.011 \\
(1.97)\end{array}$ & $\begin{array}{l}-0.022 \\
(-1.02)\end{array}$ & $\begin{array}{r}-0.027 \\
(-1.28)\end{array}$ \\
\hline Percent large employers & $\begin{array}{r}0.005 \\
(1.49)\end{array}$ & $\begin{array}{r}0.006 \\
(1.62)\end{array}$ & $\begin{array}{c}-0.016 \\
(-0.88)\end{array}$ & $\begin{array}{l}-0.051 \\
(-2.62)\end{array}$ \\
\hline Percent uninsured & $\begin{array}{l}-0.0004 \\
(-0.11)\end{array}$ & $\begin{array}{c}-0.001 \\
(-0.16)\end{array}$ & $\begin{array}{c}-0.014 \\
(-1.57)\end{array}$ & $\begin{array}{l}-0.012 \\
(-1.32)\end{array}$ \\
\hline Percent Medicaid & $\begin{array}{r}0.005 \\
(1.32)\end{array}$ & $\begin{array}{r}0.005 \\
(1.21)\end{array}$ & $\begin{array}{c}0.006 \\
(0.65)\end{array}$ & $\begin{array}{r}0.007 \\
(0.82)\end{array}$ \\
\hline
\end{tabular}

Note: t-statistics in parentheses, and intercept not shown. $\mathrm{N}=1,000$ in columns 1 and 2, $\mathrm{N}=400$ in columns 3 and 4. 